\title{
Research on Marxism national cultural soft power
}

\author{
Guangying $\mathrm{Yi}^{1, \mathrm{a}}$ \\ ${ }^{1}$ Northeastern University, Shenyang,Liaoning, In chinese \\ ayiguangying@sina.com
}

Keywords: Cultural creative industry, Marxism, Cultural soft power

\begin{abstract}
Cultural creative industry as China's emerging cultural industry, international development prospects, on the basis of the theory of Marx's culture, expounds the source of the cultural creative industry and its significance, connotation, basic features, is of great significance to our country the construction of cultural soft power.
\end{abstract}

\section{Introduction}

In general, we will think the traditional concept of social production is divided into two opposite material production and spiritual production areas, and the same is in the concept of traditional culture, people also put the cultural understanding as the spirituality of literature and art, so cultural production is belongs to the category of spiritual production, is regarded as the spiritual and aesthetic productive labor, and is thus opposed to material production.

\section{Karl Max's theory of culture and the connotations and origin of cultural creative industry}

Cultural and material opposite idea is firmly opposed to Williams. Williams insisted that culture as a kind of ideographic practice and overall way of life, is part of the whole social practice. Whatever the purpose of cultural practices, cultural mode of production is indisputably material. Cultural production means either rely on the body's internal resources, external material or rely on the human body, in either case are physical. "According to the historical evidence of mental labor productivity inevitably has the material itself, and hence social history."[1] Culture, not only is a kind of spiritual phenomenon, is also a kind of productivity. It is shown as two forms: the productivity of direct and indirect productivity. We speak of culture is different from the previous traditional culture, it is the essence of traditional culture, to adapt to the new era of development, the new form: cultural creative industry. Raymond Williams (1921-1988), the western marxist thinkers in the 20th century, literary critic and cultural theorist, the founder of the British cultural studies, according to Williams' cultural materialism, culture, as the society as a whole way of life, is a special kind of social practice activities, is a kind of social and material production process. That is to say, the creation and development of culture, is also a form of human social production, the production of culture. The so-called cultural production, generally refers to the industrialization of cultural goods or feeling, consciousness or meaning of social production. Cultural production "emphasizes the institutional features and social culture, and relative to the widely held belief that culture is the result of individual inspiration and imagination."[2] Culture of institutionalization and socialization in Williams' cultural sociology thought, is the material characteristics of cultural production. In his view, "once the cultural production itself is seen as a social and material, the whole social process inseparable sex have a different theoretical basis." [3] It is established on the basis of the theory, Williams of cultural sociology thoughts formed the cultural mode of production and reproduction theory as the main body of the research paradigm of cultural production. Williams to distinguish the human body internal resources and external tools using two kinds of culture mode of production, also distinguish between the copy and the way of innovation of two kinds of cultural reproduction, whatever the purpose of cultural practices, cultural means of production has arguably material.

Meallsof production is a core concept of marxist theory, in fact, in the production theory of marxism, production mode is the unity of productivity and production relations. "Production mode said specific combination of productivity and production relations, including the existing means of 
production, productivity is not only technology and raw materials, and the development of human; " [4]Use and economic activities of production relations including production means of products, and production system. So it will be from the narrow idea of technical production mode, "economic" on the contrary, it is in itself a complete social organization. Famous contemporary western marxist thinker Jameson (FredricJameson) mode of production is regarded as "the code" of marxism, he thought that the problem of the mode of production 'framework' is today in all disciplines of marxist theory of the most dynamic new area "[5]Eagleton, divides into the marxist criticism of anthropology, politics, ideology and economic four patterns. Economic model of the main issue is the production mode of culture: its main concern is neither specific literature, nor abstract social configurations, but production culture all material set up among the areas, and the printer from the theatre to the literary circle and sponsor system, from the rehearsal, reviews producer and receiver's social context, are among them.[6] Mode of production of western marxists, and become a cultural analysis and ideological analysis of an important category. According to rely on the material carrier of cultural production, Williams distinguishes between two kinds of culture mode of production: one is completely or mainly rely on the human body itself inherent physical resources of the cultural production, such as oral, singing and dancing, poetry and other forms of art; Another is completely or mainly using outside human objective object or power of cultural production, such as painting, sculpture and other art form material basis, on the other hand also provides the classification principle of a kind of art form, this undoubtedly has important significance for culture and art development.

Cultural creative industry is the result of the creative industries, in May 1997, the British prime minister Tony Blair for the revitalization of the UK economy, proposed and promote forming the creative industry task force. The team in 1998 and 2001, respectively, released two research reports, analysis the status quo of the creative industry and development strategy is put forward. In 1998, the creative industry for the first time for creative industry is defined by a special working group, the creative industries as "derived from individual creativity, skill and talent, through the development and use of intellectual property has the potential to create wealth and employment industry". According to this definition, the British will advertising, architecture, art and cultural exchange, arts and crafts, design, fashion design, film and interactive leisure software, music, performing arts, television broadcasting, publishing, software, and other industries identified as creative industries. The United Nations educational, scientific and cultural organization that cultural creative industry contain cultural products, cultural services with three contents of intelligent property right. In recent years, Europe, America, Australia and other countries report and research achievements, greatly enriched the connotation of the creative industry.

\section{The research status quo of cultural creative industry}

In recent years, the "culture industry", "cultural creative industry" can be very hot topic, more time to everyone to stay in the discussion of the concept level, the "cultural creative industry" or "cultural industries", many scholars have domestic theoretical circle around the different aspects of cultural creativity industry put forward all kinds of claims. Some people think that the cultural industry is mainly to create some eye-catching cultural products, such as TV, video products, etc, therefore is called "eyeball economy". Some people think that culture creative industry competition is mainly on how to compete for the attention of the audience, and addresses the attention of the audience a variety of economic value added service, therefore is called "attention economy". Others according to the associated with China's rapidly growing number of traffic radio show profit model puts forward the concept of the "ears", these claims are not comprehensive, points out the core essence of cultural creative industry. Creative industry from Britain's first, followed by many countries and regions have also put forward the related concepts. Mainly includes the copyright industry, cultural industry, leisure industry, experience economy, the concept of the attention economy. Major countries and regions of the world's understanding of the creative industries are divided into three types: type "copyright", represented by the United States, represented by the "creative", represented by, Korea in "culture form". 
In developed countries, call it "culture industry" or "creative industries", the history of the development of the industry itself is pretty long. "Creative industries" of Britain, South Korea. The rest of Europe to some call it "culture industry". In the United States is not the concept of "cultural creative industry". The United States is a high degree of the rule of law, all products of creativity is intellectual property, such as painting, song, dance, TV shows, radio shows are copyrighted and not copied to others without authorization. So they called the related industry basic "copyright industries". It seems that the concept of cultural creative industries in developed countries as is not exactly the same.

Cultural creative industry in our country is in comparison with traditional cultural industries. Traditional culture industry mainly includes the book publishing, news media industry, radio, film and television industry, the performing arts industry, advertising industry, etc., as time changes, gradually to develop a new form of industry, such as Cultural Creative Industries Cultural and Creative Industries, is a kind of economic globalization under the background of the creativity as the core of the emerging Industries, emphasis on a subject or Cultural factors depend on personal (team) through the industrialization of technology, ideas and ways of industry development, marketing, intellectual property rights. Cultural creative industries including radio, television, film, animation, video, media, visual arts, performing arts, crafts, sculpture, environmental art and design, advertising, decoration, costume design, creative groups in aspects of software and computer services. Cultural creative industry is to culture as a kind of direct productivity, highlighted in the social and cultural benefits at the same time generate economic benefits.

\section{The basic characteristics of cultural creative industry}

High knowledge. Culture as a cultural creative products generally, creative concept as the core, is people's knowledge, wisdom and inspiration in the material form of the specific industry. Culture creative industry and information technology, communication technology and the wide application of automation technology and so on are closely related, shows the characteristics of high knowledge and intelligent. Such as the creation of the film, television, and other products with the photoelectric technology, combining the computer simulation technology, media, etc.

High added value. Cultural creative industry in technological innovation and r\&d industry value chain link, is a kind of high value-added industries. Culture creative product value, the added value of science and technology and culture is notably higher than ordinary products and services.

Strong convergence. Culture creative industry as an emerging industry, it is the product of the mutual fusion, such as economy, culture, technology, with high integration, strong permeability and radiation, for the development of emerging industry and its associated industry provides a good condition. Cultural creative industries in giving impetus to the development of relevant industries and promote regional economic development at the same time, also can radiation to all aspects of the society, improve people's cultural quality.

The development of cultural creative industry, rely on people, the most core is the release of the people's creativity and liberation. Marxist theory suggests that only talent is the foundation of all social production and the main body, people itself is the basis of his own material production, is also the basis of a variety of other production he. There is no doubt that the cultural production is based on humanistic as fundamentally. According to marxist theory, the development of human society is in essence the humanization of nature. In Williams's view, cultural production as the senior form of human activities, its "the humanization of nature" including "man's inner nature" and "lies in the human nature" [7] the humanization of the two aspects of the process. Generally speaking, people are in the process of using external physical world or transform into the social relationship. General material or the process of cultural production, people tend to stress the material carrier of nature or the use of power, for the use of the human body inner resources are lack of enough attention. Despite the social relations, especially the changes in the social relations, in the people in the process of the use of external material carrier or power reflect more obvious, but through the body's own internal resources of cultural production and development, reflects the significant social characteristics is worth emphasizing. Generally speaking, human beings are in the use of material tools or transformation in 
the process of the objective material world, and establish a social relationship. The external material object or human use the power of invention and reform will inevitably bring the change of social relations.

\section{The development of cultural creative industry and enhance the national cultural soft power}

China's "cultural creative industry" really developed need to fully release the creativity of the Chinese people, to improve the quality of the people, a person of infinite innovation ability can be maximum. Or any cultural heritage resources is not going to be a natural products or commodities, only through some form of creation, to become a rich cultural products of intellectual property rights. Literacy, the artist's creative ability can say is the culture of "technology"; At the same time, they create the social atmosphere, system condition is part of this kind of "technology".

Due to the rapid development of globalization and informationization, the trend of world economic integration and regional economic collectivization, the enterprise market environment facing the so, great changes have taken place in the competition between the enterprises gradually from confrontation to cooperation. Creative industry alliance as a win-win strategy mode, has become the enterprise organizational innovation cooperation, integration of resources, forming the core cohesion, an important means to improve their competitiveness and highly effective organization innovation. China's creative industry alliance in the capital Beijing and even the rapid development of the national economic and social great environment, relying on the relevant branch of CPPCC national committee, the relevant ministries and commissions of the state, the union expert committee, relying on the beijing-tianjin-hebei creative industry talents and application market the advantage of relatively concentrated, since it was founded, guide the industrial cluster innovation in the field of cultural creative industries, promoting industrial quality and ability of market competition increasingly prominent role. Union grasps "the innovation of service, friendly cooperation, joint force"[8] principle, by organizing mode innovation, system innovation and mechanism innovation, convergence industry resources, insist on joint innovation and development, in the long run is difficult to realize the officer, production, study and research, information, use the organic combination has made the substantial breakthrough and progress.

\section{Summary}

From the strategic point of view, development of cultural creative industry helps to promote cultural construction of power, and from the point of the development of the national actual, the development of cultural creative industry, will speed up the country's economic, political, cultural, and better development of the society. Culture creative industry has transcended the traditional cultural industry, its positive significance lies in through fusion penetration, promote industrial innovation and structure optimization, thus promote innovation in all areas of the economy. All walks of life can be with the development of cultural creative industries, or application of its results, update the design of the products and services, planning, opening up new brand strategy and marketing strategy.

\section{References}

[1]Raymond Williams. What I CameTo Say, London: Hutchinson Radius, p.211.

[2]John fiske compilation: such as the dictionary of key concepts: communication and cultural studies, Arthur, Beijing: xinhua press; (2003)p. 68

[3] Wilaymond Williams. Politics and Letters: Interviews with New Left Review s. London: Verso(1981)p.139.

[4] Jacques Attali: "Karl Max", translated by Liu Chengfu, Shanghai people's publishing house, 2010 edition, p.2. 
[5] Frederic Jameson, "the political unconscious," the king PangZhen Chen Yongguo, Beijing: China social sciences press(1999) p. 116

[6] British terry eagleton: the history of politics, philosophy, lust, Ma Hailiang, Beijing: China social sciences press(1999) pp. 117-116

[7] Giddens:Modernity and Self-identity,(Stanford University Press,1991),pp.36-42.

[8] F.A. Hayek, The Road to Serfdom(Chicago:The University of Chicago Press,1994),pp.16-19. 